Meta

Journal des traducteurs

Translators' Journal

\title{
Towards a Whole-Person Translator Education Approach in Translation Teaching on University Degree Programmes
}

\section{Zaixi Tan}

Volume 53, numéro 3, septembre 2008

URI : https://id.erudit.org/iderudit/019241ar

DOI : https://doi.org/10.7202/019241ar

Aller au sommaire du numéro

Éditeur(s)

Les Presses de l'Université de Montréal

ISSN

0026-0452 (imprimé)

1492-1421 (numérique)

Découvrir la revue

Citer cet article

Tan, Z. (2008). Towards a Whole-Person Translator Education Approach in Translation Teaching on University Degree Programmes. Meta, 53(3), 589-608. https://doi.org/10.7202/019241ar
Résumé de l'article

Cet article postule que l'enseignement de la traduction en milieu universitaire ne correspond tout simplement pas à une formation de traducteurs. Il est plutôt à la fois une formation et une éducation, et souvent plus une éducation qu'une formation. À partir de cette constatation, il est important de prendre en compte le développement holistique des étudiants dans leur éducation en tant que traducteurs/spécialistes de la traduction. L'essentiel du modèle que cet article propose de développer s'exprime par les deux concepts componentiels, à savoir, le " whole-person translator education » et le «translator-development pyramid ». Les deux concepts, ainsi que des questions sur la compétence en traduction qui sont intégrées pour créer une « whole-person » chez un étudiant en traduction, sont analysés et discutés à fond, afin d'éclairer le développement de ce qui pourrait être un modèle pédagogique innovateur pour l'enseignement de la traduction. 


\title{
Towards a Whole-Person Translator Education Approach in Translation Teaching on University Degree Programmes'
}

\author{
ZAIXI TAN \\ Hong Kong Baptist University, Kowloon Tong, Hong Kong \\ thtan@hkbu.edu.hk
}

\begin{abstract}
RÉSUMÉ
Cet article postule que l'enseignement de la traduction en milieu universitaire ne correspond tout simplement pas à une formation de traducteurs. Il est plutôt à la fois une formation et une éducation, et souvent plus une éducation qu'une formation. À partir de cette constatation, il est important de prendre en compte le développement holistique des étudiants dans leur éducation en tant que traducteurs/spécialistes de la traduction. L'essentiel du modèle que cet article propose de développer s'exprime par les deux concepts componentiels, à savoir, le «whole-person translator education» et le «translatordevelopment pyramid». Les deux concepts, ainsi que des questions sur la compétence en traduction qui sont intégrées pour créer une «whole-person» chez un étudiant en traduction, sont analysés et discutés à fond, afin d'éclairer le développement de ce qui pourrait être un modèle pédagogique innovateur pour l'enseignement de la traduction.
\end{abstract}

\section{ABSTRACT}

This article posits that translation teaching in degree programmes in translation at the tertiary level is not mere translator training. Rather, it is both training and education, and very often more education than training. On this proposition, it emphasizes the need for such programmes to take into full consideration the holistic development of the students in their education as translator/translation specialist. Most essential to the model that the paper proposes to develop are its two componential concepts, namely the "wholeperson translator education" concept and the "translator-development pyramid" concept. Both of these concepts, together with issues on the various kinds of translation competences that are integrated to create a 'whole person' in the translation student, are analysed and discussed in depth, in order to shed light on the development of what could be seen as an innovative pedagogical model for translation teaching in university degree programmes in translation.

\section{MOTS-CLÉS/KEYWORDS}

translation pedagogy, holistic training, translator education, pyramid, translator competence

\section{Introduction}

In a world of fast change and development, translation is also faced with great changes and challenges, and so is the teaching of translation. First, there is the continued change in the type of texts to be translated. As Nida has noted, among the estimated two billion pages of translation being done each year throughout the world (not counting the output of some five hundred thousand members of China's professional translators association), "the translation of literary texts probably represents not more 
than one percent of the total production of translations" (Nida 1997: 9). The translation of political, juridical, technological and commercial texts is expanding so incredibly rapidly in the modern information world that the traditional patterns of translation with hands is no longer able to handle the task efficiently. Demand from the market, therefore, calls for able and qualified translators equipped with efficient technologies.

Second, the enormous volume of translation work in demand has led to the flourishing of translation agencies and the development of translation programmes across the world in the past decade, especially including China and EU countries. Pressure on translation speed and efficiency has consequently led to the rapid development of translation machines, including translation memory tools, terminology software and the Internet. As PACTE (2000) has pointed out, quite rightly, the development of translation competence in student translators today not only means the training of their linguistic-cultural skills, but also IT skills, marketing and other related problem-solving abilities as well (Mackenzie 2004: 32-33; Kiraly 1995, 2000). Obviously, this new definition of translation competence is very different from that of the more traditional translator and interpreter.

In view of these rapid changes and developments in the actual field of translation, some scholars complain about the lesser progress with the teaching of translation, saying that translation teaching in universities across the world has to a great extent been separated from translation practice since translation theory is considered to be "at best irrelevant to the professional translator and at worst distracting and misleading" (Baer and Koby 2003: VII). No doubt, there is truth in this kind of complaint. In China, for example, in spite of the rapid expansion of translation of practical texts in the Chinese translation market, nearly 95 percent of translation textbooks are still focused on literary translation. This is certainly something textbook writers on translation need to consider very carefully if they are to render their work relevant and useful. However, when we come to think of what the true relationship should be like between theory and practice, things may not be that simple and straightforward.

As we see it, there are no intrinsic properties in translation theory being a "distracting or misleading" factor to translation practice or to the teaching of translation. What does not seem quite right in the present-day teaching of translation is not that there has been excessive focus on translation theory or that translation theory is by nature "misleading" for the practice of translation; but that we need to formulise the right kind of theory for the teaching of translation and teach it the right way. But what is the right way to teach translation? And what theory is the right kind of theory for the teaching of translation? Will we lose our old way of teaching or will we embark upon a broader road of translation education in what is described by some as a "revolutionized" era of translation? (Maia et al. 2002: 9).

These and other issues will then be the basic concern of our discussion in this paper. But before we set out to unravel the "theory vs. practice" debate on what might be proposed as the right kind of model for translation teaching, especially in Chinese contexts, it would be of interest to take a look first at just what is happening in the teaching of translation in those contexts. 


\section{Overview of translation teaching and research in Chinese contexts}

The teaching of translation in the People's Republic of China, or the PRC or the Mainland of China as it is often called, has undergone great development in the last decade since 1995. That is, from the time when the Translation Research and Teaching Committee of the Chinese Translators Association was set up after the First Asian Translators' Forum was held in Beijing. In the following year, the first National Conference on Translation Teaching was convened in Nanjing in which more than 100 translation teachers of various language-pairs in the country gathered to discuss the aims, methods, and textbooks of translation teaching (Mu 1999: 21). In 1997, the Conference on Translation Teaching: China Mainland, Hong Kong, Macau and Taiwan was held in Hong Kong where Chinese translation scholars and teachers gathered in a more diversified environment to share ideas and experience on translation teaching. Attention was drawn at the conference to the need of more theoretical thinking on both translation and the teaching of translation.

As a result of mounting academic and disciplinary pressure and awareness, the first PRC translation department was set up at the Guangzhou Foreign Studies University in 1997. In the ensuing years, other institutions in Beijing, Xi-an, Shanghai and Changsha followed suit, setting up similar translation departments and schools, public or private, and offering specialized translation programmes on both the undergraduate and postgraduate levels. In February 2004, yet another major event took place, namely the setting up of a government approved postgraduate degree programme in Shanghai Foreign Studies University under the specific disciplinary name of Fanyixue (translatology or translation studies). This development has since been widely acclaimed by Chinese translation scholars as a landmark breakthrough in the country's translation education because prior to this development all designations of the degree in translation studies had been categorized under the major of either English Language and Literature (or French Language and Literature, etc., depending which language was involved), or Linguistics, or Applied Linguistics. With regard to the turnout of degree students in translation on the doctoral level, inclusive of those under the name of translation studies and otherwise, there had been a total number of 110 by the end of 2004, graduated from 14 universities across the country. Out of the 110 doctorate theses with these translation students, 67 are on the translation of literature and translation theory; 42 on machine translation, and 1 on the translation of science and technology. None of these theses, however, has dealt with the teaching of translation or any pedagogical aspects of translation.

In Hong Kong and Taiwan, especially in Hong Kong, the teaching of translation as a university major began at an earlier time. The first translation programme in Hong Kong started in the Chinese University of Hong Kong (CUHK) in 1972. Later, other universities also began to offer degrees in translation, which now include Hong Kong Baptist University (HKBU), Lingnan University, the City University of Hong Kong (CityU), the Polytechic University of Hong Kong (PolyU), Hong Kong University and the Open University of Hong Kong. Of these, HKBU, CityU, PolyU, CUHK and Lingnan University also offer degrees in translation studies on the MPhil and PhD levels. Among all the doctoral graduates in Hong Kong, two have dealt with translation teaching-related topics, one on the history of textbook development on translation in Mainland China up to1998 (Zhang 1999), and the other on a marking 
model in the testing of English-Chinese and Chinese-English translation (Mu 2004a). Both these theses are products of the doctoral programmes at HKBU, whose Translation Programme and Centre for Translation have been among the most active and productive in both translation teaching and research in the Hong Kong area.

In Taiwan, three translation institutes are particularly outstanding, the oldest one being the Graduate Institute in Translation Studies of Fujen Catholic University, first set up in 1988; and the other two being those in Taiwan Normal University and the Changrong College of Business Management (Mu 1999: 22-23). All of these institutes offer undergraduate and/or postgraduate courses in translation, with a focus on interpreting (Mu 2004b: 38). However, as in Mainland China, no theses have been written in any of the translation programmes in Taiwan on the teaching of translation or any translation teaching-related topics, either on the undergraduate or postgraduate level.

Clearly, since the first Hong Kong translation programme started in the Chinese University of Hong Kong in 1972, impressive achievements have been made in translation teaching within the major Chinese-language environments, with translation programmes at tertiary levels offered in various universities in Hong Kong, the Mainland and Taiwan. However, reflections on translation teaching have not been quick enough in coming. Although sketchy statements can be found in some works on translation studies and academic journals especially since the early 1990s, the first systematic research on translation teaching did not appear until 1999 (Mu Lei), followed by a study of E-C/C-E translation textbooks in China (Zhang 2001), and a third on a more general frame of the theory and practice of translation teaching (Liu Miqing 2003). In addition to these monographs, there have also been two volumes of conference proceedings (Liu Zonghe 2001; Liu, Jingzhi, Lin Wusun and Jin Shenghua 2000); and among the $110 \mathrm{PhD}$ theses (as of 2004) in translation studies in the Mainland, none has dealt with the basic theory of translation teaching. The only two PhD theses on translation teaching are those produced at HKBU (Zhang Meifang 1996; Mu Lei 2004).

Admittedly, all these works are important in their own way as contributions to the study of translation teaching within a Chinese-language context. The first Chinese-language monograph on translation teaching, Mu Lei's work (Mu Lei 1999) presents not only a survey but also opinions on such important aspects about translation teaching as curricular design, textbook development, teaching time distribution and the training of translator trainers. The second monograph, published by Zhang Meifang in 2001, is based on the author's doctoral thesis at HKBU as mentioned above. A study of coursebooks on E-C and C-E translation in China, it analyses the guiding principles underlying more than 100 translation textbooks in the Mainland of China and takes a market- and function-oriented approach to what textbooks are to be considered fitting for the teaching of translation.

Liu Miqing's book on translation teaching (Liu Miqing 2003) aims to offer a more general theoretical frame for translation teaching. Its basic argument is that translation teaching should be oriented towards a holistic "quality education" in which teaching is targeted at the improvement of the overall quality of students and its success relies on the use of effective teaching methods; and that, in order to achieve this goal, the focus of teaching should be placed on that of translational "universals" and "fundamentals," rather than translational "specifics" and "specials" (Liu Miqing 2003: 27-30). 
The Proceedings of Conference on Translation Teaching (Liu, Jingzhi, Lin Wusun and Jin Shenghua 2000) was the first collection of papers on translation teaching published in Hong Kong, covering a wide range of topics on the teaching and learning of translation, including translational curricular design, translation theory and its teaching, translation and interpretation practice, and so on. Likewise, the other collection of articles (Liu Zonghe 2001), a combination of selected papers from the first national Conference on Translation Teaching held in Nanjing in 1996 and selected journal articles on translation teaching recently published in China, covers similar topics ranging from general translation theory to teaching theories of translation, from textbook writing to the methodology of teaching, from translation criticism to translation assessment, and so on and so forth.

One of the important contributions made by these works is the awareness they brought about among Chinese scholars that there is so much to know about translation teaching, and that we do not simply go and teach, but we need to be theoretically equipped in order to teach better.

On top of all these developments in the Mainland, very important contributions have come from the research work conducted by Li Defeng in Hong Kong. In his many papers on the teaching of translation in Hong Kong, Li carried out interesting and critical examinations of the curriculum design and teaching methodology of specialized translation courses (including courses on commercial translation, government document translation, science and technology translation, mass media translation, and legal translation). Emphasising the importance of tailoring translation programmes to social needs, he made valuable suggestions on how to improve the course content and teaching methodologies in line with educational curricular theories and thoughts on translation teaching (Li Defeng 2000; 2002; 2003; 2005 ).

However, in spite of all such progress and advances, limitations in translation teaching and research have remained, and such limitations are not merely confined to the work done in China, but some are also found in the work done in a worldwide setting as well. For example, little attention in either China or elsewhere has been directed to the study of how quality control can be done in the training or education of translation students on their various levels, from the undergraduate to the MA and MPhil to the PhD level. What is the relationship in each of the major stages of education between the students' translating competence and their research capability on translation topics? What differences should there be in curricula, teaching methodology and educational aims and objectives, etc., between translation students and foreign language students who may also take up jobs as translators and interpreters? And so on. But limited by space, we shall not be dealing with limitations of this kind in great detail. Rather, of all the limitations and problems with researches that have been done on translation teaching, we will be more concerned with the following two because they bear most strongly on our view of fundamental problems in translation teaching research.

First, there is the lack of understanding of the true nature of translation teaching in university translation programmes, especially in terms of its purpose and the kind of end products it aims to have. As is currently done, translation teaching does not seem to be complying very well with the true mission of higher education, because it focuses too much on the techniques or the various technical competences required of students, and not so much on the education of students as creative, intelligent and 
competent human beings equipped with well-rounded translation competences more than with a narrow set of techniques. As is commented on by some scholars, this lack seems to be the result of a neglect to maintain balance between what they call "the Dao" (the way) and "the technique" in translation teaching (Yang and Zhang 2003). According to Sylvia Bernardini (2004: 19-22), this is because people do not fully understand the important distinction between "translator training" and "translator education" for university translation programmes. In any case, this need for a fuller understanding of the true nature of translation teaching remains an important immediate challenge to us in both the translation teaching and research fields.

And second, in spite of the research efforts that have been made on a wide range of topics on translation teaching, especially on topics concerning the hows, there is still a need to bring some of the important wh-questions into more in-depth discussions. In other words, much more remains to be unravelled with regard to an integrated discussion of the whys, whats, hows and whens in the teaching of translation, namely why, what, when and how do we teach to make a university translation programme successful? Although these may seem familiar issues, they are nevertheless worth looking into again especially when put in a new perspective and viewed in a new light.

To unravel the above concerns, we shall move on to the next section and try to present what we believe to be a fitting model for the teaching of translation in a university translation programme.

\section{Application of the whole-person concept for a new model of translator education}

As a special course for language students at the advanced college level, the teaching of translation is no doubt aimed at the skills training of language students, providing them with a deeper understanding and a fuller command of language skills. Recent calls for translation courses to be given to all non-language majors in Chinese universities have been a reflection of the realisation that translation courses are indeed important for the training of the students' language skills.

Likewise, in the translation programmes in the newly established schools of translation and interpretation in China's key foreign language or international studies universities in Beijing, Shanghai and Guangzhou, as well as in many of the older translation departments of other universities, translation is also mostly skills- and translation training-oriented. The same is true of translation programmes in such French universities as Université Paris III, Université Rennes 2, and Université Lumière Lyon 2, where the primary goal of translation teaching is also chiefly skills-trainingoriented. So is Anthony Pym's two-year Masters course, whose objective it is "to develop a broad range of professional skills in technical translation." ${ }^{[2]}$ In other words, it seems to be a universal phenomenon for translation teaching to be skills-oriented whether in a language programme or a specialised translation programme.

Therefore, schools and departments of translation programmes usually enrol students who are well-qualified in both languages, especially in L1, and devote most of the study time to students' development of translation skills and competence. In this sense, translation programmes below the doctoral level are mostly accelerated training programmes. 
But is this the right model of translation teaching for university translation programmes? The answer is both yes and no. Yes, because translation students must be trained to translate with enhanced skill; and no, because a university translation programme is not and should not be the same as a translation programme in a training school or translation course for a non-translation major programme at university. In other words, just as a fundamental distinction should be drawn in language pedagogy between training and education (Widdowson 1984: 201-212), a clear distinction must also be drawn between translation teaching as training and that as education (Bernadini 2004). To a large extent, our proposal for a new model of translation teaching is based on this very concept of translation teaching as both training and education. But before we proceed with our proposal, let us take a further look at the general distinction between training and education. Following is what Widdowson has said on the issue:

I want to suggest that training is directed at preparing people to cope with problems anticipated in advance and amenable to solution by the application of formulae. Training in this sense is oriented towards specific aims. But education... is directed at developing general intellectual capacity, cognitive sets, attitudes, dispositions which, it is supposed, can be subsequently brought to bear to deal with any eventuality that may arise. Education, in this sense has a general, not a specific, orientation. (Widdowson 1984: 207)

The purpose of training... is to establish close formulaic links between areas of theory and practice, ... so that problems can be accounted for by the application of formulae within minimum adjustment. The purpose of education, on the other hand, is to allow for a disparity between theoretical system and practical schemata, and to provide for the general procedural ability to mediate between the two and to solve problems by referring back to principles and checking them against particular situations. Education, in other words, is in the business of developing the ability to negotiate solutions to problems that do not correspond in any obvious way with pre-existing formulae. (Widdowson 1984: 208)

\section{As Bernadini understands it:}

Learning through training is a cumulative process, in which the learner is required to put together as large an inventory of pieces of knowledge as possible in the field in which she is being trained. ...Learning in an educational framework is viewed as a generative rather than cumulative process, whose aim is to develop the ability to employ available knowledge to solve new problems, and gain new knowledge as the need arises. In other words, the ability to use infinite resources indefinitely is a result of education, not training. (Bernadini 2004: 19-20)

This distinction, as is made by Widdowson, is very important and can "help us shed light on the priorities of translation teaching, and on the differences distinguishing undergraduate from postgraduate courses" (Bernadini 2004: 20). Training and education are used for different purposes in teaching, just as Bernadini has described (2004: 19-20), the former aiming at accumulative knowledge acquiring process when the shortterm objective and the long term objective coincide to a great extent, while the latter seeks the growth of individuals and their long-term empowerment with generative problem-solving abilities. Both training and education can be used in course instruction according to different student needs. Often, however, language teaching methodology "will need to correspond to the more general educational requirements of intellectual enquiry and the solving of unpredictable problems" (Widdowson 1984: 211). 
In this information age, new knowledge pops up every minute. Young people today "are exposed to more new information in a year than their grandparents encountered in a lifetime" (Weber 1999: 9). They "have to face a world subject to dramatic changes, a world where our know-how doubles every five years, where the very web of social structure is modified continuously, where stable jobs are on the wane, and where work conditions and professional abilities are renewed every day" (Blasi. 1999: 28). It is quite necessary for young people to gain generative problemsolving abilities, using definite resources to handle infinite new situations. The capacity to learn and solve problems by themselves has become crucial. Just as Donald Kiraly has noted:

It is impossible to predict years in advance what particular topics one will work on after graduation or over the course of one's career. A well-developed ability to adapt to ever-changing market demands is crucial. Thus, knowing how and where to research new topics adequately and efficiently is an essential skill for translators to acquire. (Kiraly 2000: 12)

Therefore, it is high time to rethink the pedagogy in translation, and work out well designed programmes in translation education, instead of seeking fast but short-sighted translation training. Things have changed so much in the translation market that Kiraly suggests that we "reconsider the viability of conventional approaches for educating translators, which date back almost half a century, when the translation profession was something altogether different from what it is today" (Kiraly 2000: 14).

That teaching translation is far more than just training is also firmly supported by the institutional establishment of translation programmes covering a full range from the undergraduate through postgraduate (taught MA and research MPhil) to doctoral and postdoctoral levels. Translation pedagogy should certainly not neglect this complete list of tasks in the whole range of translation programmes and focus entirely on the otherwise important part of professional training of translators and interpreters.

What then is the most distinctive feature of teaching translation as both training and education? Our answer to this question is found in the "whole-person education" concept. We will thus term our new model as a "Whole-person Education Approach to Translation Teaching."

To fully understand just what is meant by this whole-person education approach to translation teaching, there are two crucial elements about the approach that need specifying, namely the "whole-person education" concept and the "developmental pyramid' concept. First, the "whole-person education" concept. The core element in our model, this concept is a borrowed concept from the general missions and goals of higher education adopted by many universities world-wide in the new millennium, HKBU included. In its general missions statement, HKBU defines the features of its whole-person education model as being a holistic approach, broad-based, creativity-inspiring, inculcating in all who participate a sense of human values, and maintaining strong links with the community. Simply put, a whole-person education would make students "well-rounded," "well-adjusted" and "adaptable" (Bligh 1990: 11). As university translation programmes are but part of the university system, the general missions of the university are definitely also missions of all its programmes, including its translation programme. However, this is not the main idea of what is 
meant by our "whole-person education" model for translation teaching. What is central to our model is that translation teaching in a university translation programme should aim at educating its students in an all-round manner. By "all round" is meant that in addition to educating students as a "whole person" in the general sense, they should be educated as a well-rounded translation specialist in the particular sense. Such a specialist is not only specialised in special areas of knowledge and expertise on translation, but more importantly, he/she has developed more general abilities to meet all kinds of challenges in translation. In other words, they should have a broad translation-knowledge and skills base, be able to think critically and creatively about the process and product of translation, have command of the basic translation competence and techniques, and be equipped with general occupational skills in addition to job-specific techniques.

But how is this core element of "whole-person education" materialised? It is materialised through a "healthy" way of operation or practice. The reason why we use the word "healthy" is that the way in which a "whole-person" translator or translation specialist is developed is very much like the way a healthy diet is composed for the development of a healthy body. Basing ourselves on the dietary guidelines created by U.S. nutrition officials in the form of the Food Guide Pyramid, ${ }^{[3]}$ we will call our model the Whole-person Translator Education Pyramid, or rather the Whole-person Translator Education Inverted-Pyramid, because the development model we will present is in fact in the shape of an inverted pyramid and not exactly the same as the nutrition officials-provided Food Guide Pyramid. In the Whole-person Translator Education Inverted-Pyramid, development of the translator starts from a "zero" base, as it were, and radiates upwards. In other words, at the beginning, the student or the trainee-translator or trainee-translation specialist has minimal translational knowledge and competence. As he/she progresses in the education/training process, his/her knowledge and competence in translation grows, and this growth is made possible through education/training in the practice and theory of translation. Just as eating foods from the Food Guide Pyramid will help children grow healthy and strong, providing a balanced scientific "diet" for the benefit of students in a translation programme, from undergraduate through postgraduate to doctorate levels, will also be the right way to make the students grow "healthy" and "strong."

The central idea about the Food Guide Pyramid is its emphasis on a wellbalanced diet, a diet that "[e]mphasizes fruits, vegetables, whole grains, and fat-free or low-fat milk and milk products; [i]ncludes lean meats, poultry, fish, beans, eggs, and nuts; and [i]s low in saturated fats, trans fats, cholesterol, salt (sodium), and added sugars." ${ }^{[4]}$ By analogy, the central idea about a healthy translator education pyramid is also the emphasis on a well-balanced distribution of what is taught and how it is taught so that a "healthy body," the translation student, is well developed. Most typical of the translational pyramid is such a balanced distribution at the level of the undergraduate degree, where the practice (skills-oriented) subjects take up the larger proportion at the base while the theory (knowledge-oriented) subjects take up a smaller proportion towards the upper part of the pyramid. Within both the practice and the theory subjects, a further balance is to be maintained, namely a balance in the types of text material to be used in the practicum (ranging from literary to legal, business, technological and other types of texts), and in the kind of knowledge to be imparted in the theory area (ranging from "linguistics for translators" and 
"contrastive language studies" to "translation methods," "translation history," "translation theories and philosophies," "research methodology in translation" and so on).

In more conventional terms, this Whole-person Translator Education Pyramid means making provisions for the translation student to develop in all ways, in psycho-physiological well-being and in intellectual capability, in theory and in practice, in abilities and in techniques, and so on. From a reservoir of terms related to this "inverted" Pyramid, we may perhaps focus on "competence/competences" as the keyword.

It must be pointed out that although translational "competence" is one of the most commonly used terms in translation teaching literature, there is in fact no consensus on its definition. What is this "translation competence"? No one has so far said anything clear and definite about it (Huang 1997: 26; Sin 2000: 14). In almost all cases, the term is simply used as a cap over many different sub-competences, and scholars have generally very "wisely" avoided its exact definition and turned to focus on discussions about the training of this or that sub-competence. They have tended to "break translation competence down into a set of interrelated sub-competences, which can be studied in isolation" (Schäffner and Adab 2000: ix). Therefore, what we normally get are such answers as: Translation competence is bilingual competence, bicultural competence, creative competence, thinking competence, expressive competence, extralinguistic competence and transfer competence (Huang 1997; Sin 2000; Liu 2003).

According to Nord (1999), it is the "translational text competence," consisting of meta-competence, text-production competence, text-analytical competence, and contrastive text competence. And in the view of Neubert $(1994,2000)$, it is language competence, textual competence, subject competence, cultural competence and transfer competence. In Mackenzie's view (2004: 32-33), translation competence includes not only linguistic-cultural skills, but also interpersonal skills, IT skills, marketing ability, even management skills, since quality in translation requires management of the whole process. All these are but what Schäffner and Adab have termed as sub-competences.

Some argue that it is only "transfer competence" that can be called translation competence. This competence is "the ability to solve problems of translation, instead of problems of language and knowledge, to establish and justify the correspondents between the source language/text and the target language/text" (Sin 2000: 22; my translation). And PACTE group holds that it is the "transfer competence" of the translator, which, as the central competence, integrates all the others (PACTE 2000: 103).

Evidently, no consensus has been reached among scholars as to what translation competence is. However, to unravel the basic problems of translating teaching, it is important to properly define what "translation competence" is. As we see it, there is nothing wrong with the use of "sub-competences," because by explaining the term in this way we may gain a fairly concrete picture of what its connotations are. Therefore, rather than abandoning this methodology altogether, we would like to follow the basic line of thought in our description. However, instead of focusing on the various "material" aspects of the translator's competence, we would like to view issues from the perspective of the "whole person" in the translator/translation specialist to be educated. Viewed as such a "person," the translator/translation specialist should then be equipped with these basic "sub-competences": competence in cognition; competence in the relevant language-pairs; competence in the tools/technolo- 
gies used to assist translation; and above all, competence in transfer between the relevant language-pairs, which may be called "translation competence proper." It is the "whole person" thus equipped or empowered that can translate, and not the various "competences" that can translate. This shift of perspective is very significant for our model because it is closely related to whether the translation programme is "person-oriented," or "materials-" or "skills-oriented."

As a whole person, the translator/translation specialist not only needs to acquire the translation competence proper, i.e., the transfer competence; but he/she should acquire the translator competence, to use Donald Kiraly's term (1995: 13; 2000: 13). But our concept of "translator competence" means more than Kiraly's term. In addition to what Kiraly calls the ability to "identify and appropriate norms in new communities to which we seek access" and "to use tools and information to create communicatively successful texts that are accepted as good translations with the community concerned" (Kiraly 2000: 13-14), but it entails all the other abilities or competences the translator/translation specialist needs for efficient work. We can tentatively define our "translator/translation specialist competence" (or "translator competence" for short) thus: "Competence that comprises all the fundamental sub-competences one possesses in order for one to be qualified as a translator/translation specialist." And these fundamental sub-competences include the above-mentioned four, namely: "competence in cognition; competence in the relevant language-pairs; competence in the tools/technologies used to assist translation; and competence in transfer."

As is generally understood by translators and translation studies people, translation is interlingual/intercultural communication, and all the abilities needed for successful communication are called "communicative competence." For our purpose, we would like to use this term to refer to the "competence in the relevant languagepairs" required of the translator/translation specialist being trained and educated.

A term originally coined by Dell Hymes in the late 1970s, "communicative competence" (SIL International 1999) has now evolved to cover two types of aspects, i.e., the linguistic aspects [of communicative competence] (or linguistic competence for short) and the pragmatic aspects [of communicative competence] (or pragmatic competence for short). Both of these each contain four sub-competences. The former comprises "phonological competence," "grammatical competence," "lexical competence," and "discourse competence"; while the latter "functional competence," "sociolinguistic competence," "interactional competence," and "cultural competence."

The linguistics aspects of communicative competence are those that have to do with achieving internalised knowledge of linguistics elements and structures. Phonological competence refers to the ability to recognise and produce the distinctive meaningful sounds of a language; grammatical competence the ability to recognise and produce the distinctive grammatical structures of a language and to use them effectively in communication; lexical competence the ability to recognise and use words in the way speakers of the language use them, including understanding the different relationships between groups of words as well as the collocations of words; and discourse competence, the ability to understand and construct texts of different genres, such as narrative texts, descriptive texts, procedural texts, expository texts, persuasive texts and argumentative texts, and the ability to relate information in a way that is coherent to the readers and hearers according to the specific context of situation, e.g., to know how to use language coherently in specialised communities. 
The pragmatic aspects of communicative competence are those that have to do with how language is used in communication situations to achieve the speaker's purposes. Functional competence refers to the ability to accomplish communicative purposes in a language, such as greeting and requesting. Sociolinguistic competence is the ability to interpret the social meaning of the choice of linguistic varieties and to use language with the appropriate social meaning for the communication situation. Interactional competence involves knowing and using the mostly-unwritten rules for interaction in various communication situations within a given speech community and, including, among other things, knowing how to initiate and manage conversations and negotiate meaning with other people, and also knowing what sorts of body language, eye contact, and proximity to other people are appropriate, and acting accordingly. Cultural competence is the ability to understand behaviour from the standpoint of the members of a culture and to behave in a way that would be understood by members of the culture in the intended way. Cultural competence therefore involves understanding all aspects of a culture, especially the social structure, the values and beliefs of the people, and the way things are assumed to be done.

Communicative competence of a translator/translation specialist concerns both languages involved, namely L1 and L2 or SL and TL, as it is generally assumed that a translator should be a bilingual or a bicultural language user. But translator/translation specialist competence goes beyond that. It takes into account another important component: transfer competence, which distinguishes translators/translation specialists from other bilingual/bicultural language users. As pointed out above, the transfer competence is the translation competence proper, entailing knowledge of the linguistic and cultural differences between the two languages involved, and the acquiring of specific skills and techniques to get over these differences in translation. Just as is understood by the PACTE group, "transfer competence is the central competence that integrates all the others"; "[i]t was...the ability to complete the transfer process from the source text to the target text" (PACTE 2003: 83). Comparative linguistics, comparative text typology, and comparative study of cultures account for much in this respect.

Apart from these above competences, there are two other competences required of translation students, namely "instrumental competence" and "cognitive competence." "Instrumental competence" refers to knowledge and skills in consulting and using relevant dictionaries, encyclopaedic references, internet resources, terminology banks, MT software, parallel corpora, and computers, etc., to assist their translation, especially in the increasing requirement of speed, documentation, and standardization in translation. The instrumental competence is "the knowledge and abilities associated with the practice of professional translation" (PACTE 2003: 83). The instrumental competence is an additional component that is required according to the subject matter and the development of society.

Likewise, it is important to note that the student, as a person, is a cognising subject, who has the ability to experience and cognise. In fact, this cognitive competence is a primary competence that is already possessed by the student and is awaiting further enrichment. By "cognitive competence," we mean the level of a person's cognitive and psychological development, the level of knowledge about the world and all factors involved in communicative situations where translation comes in and how those factors operate in these situations, inclusive of the translator's aptitudes such 
as creativity, emotional qualities and attention-span, etc. It is the translator's ability to perceive, conceptualise, evaluate, imagine and foretell the happenings and things in the social and natural world. This is what PACTE (2003) describes as the psychophysiological sub-competence. While transfer competence is "the central competence that integrates all the others," cognitive competence is the very psychological and cognitive basis of all the other competences.

All of the above components of translator/translation specialist competence develop with the growth of individuals and the development of society. Therefore, each of them broadens and opens to future development. Translator education goes hand in hand with this growth of translator/translation specialist competence and social development, and also opens to the future, with the training of listening, speaking, reading, writing and translation-operational skills graded, from the basic to the more advanced, within the process of translation teaching. Both competence development and teaching practice centre around the development of the individuals, that is, the students as cognising whole persons. In this regard, we can formulate our model into a whole-person translator education pyramid (in inverted form) with two visible facets, i.e., that of the translator/translation specialist competence and that of language teaching and learning. Both of these stretch upwards the growth of individual persons in terms of their intelligence and competence, and the development of language teaching and learning in the five basic skills. These two facets of translator/translation specialist competence and language teaching/learning form the two visible sides of a pyramid radiating upwards from a point at the base, indicating this is where a person (the would-be translator/translation specialist) is born and starts to grow. The shape of this radiating model is just like the familiar Food Guide Pyramid mentioned above, but in its inverted form, hence our description of it as the Whole-Person Translator Education Inverted-Pyramid (Fig. 1).

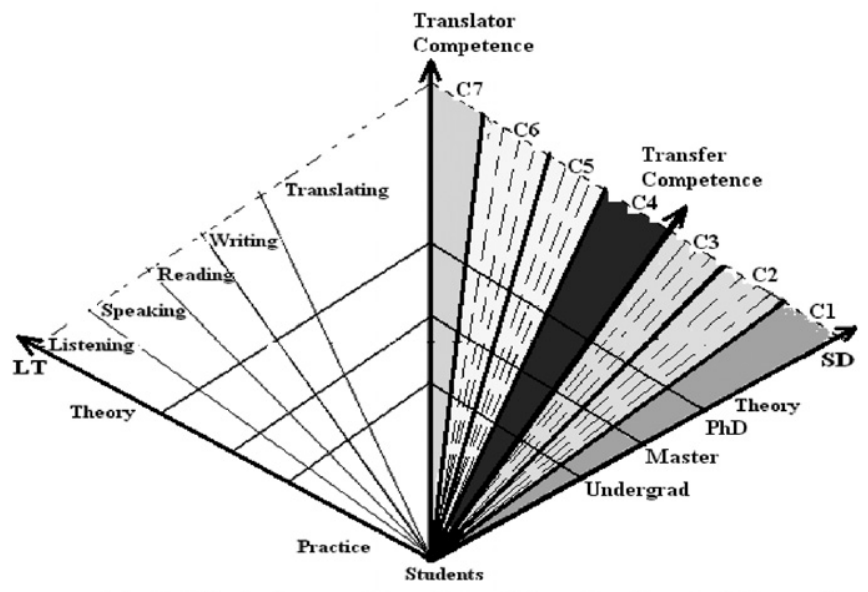

Fig.1: Whole-Person Translator Education Inverted-Pyramid

NB:

C1: Cognitive Competence

C3: $\quad$ Pragmatic Competence in L2

C5: Linguistic Competence in L1

C7: Instrumental Competence

Master: MA/MPhil Level

LT: Language Teaching

$\begin{array}{ll}\text { C2: } & \text { Linguistic Competence in L2 } \\ \text { C4: } & \text { Transfer Competence } \\ \text { C6: } & \text { Pragmatic Competence in L1 } \\ \text { Undergrad: } & \text { Undergraduate Level } \\ \text { PhD: } & \text { PhD Level } \\ \text { SD: } & \text { Social Development }\end{array}$

C2: $\quad$ Linguistic Competence in L2

C6: $\quad$ Pragmatic Competence in L1

SD: Social Development 
There are a number of points to clarify about the above diagram before we discuss the actual contents and significance in detail. First, the coloured facet of the pyramid refers to the composition of the translator/translation specialist competence, while the uncoloured facet the five basic skills in language-related courses/subjects for translation students. The use and non-use of colour are entirely for the sake of easy recognition and reference; they do not carry any special meaning beyond that.

Second, the broken lines in the various triangular segments of C2 (Linguistic Competence in L2), C3 (Pragmatic Competence in L2), C5 (Linguistic Competence in L1), C6 (Pragmatic Competence in L1) indicate that these competences are further composed of sub-competences such as the phonological, grammatical, lexical, textual, functional, sociolinguistic, interactional and cultural competences.

Third, that the blue areas of C2 and C3 are on one side of the brown area of C4 (the transfer competence) while the yellow areas on the other mean that it is this transfer competence of $\mathrm{C} 4$ that functions as the bridge linking the various competences in L2 with those in L1. This is also to confirm that the transfer competence, situated in the centre, plays the central role in the entire translation process.

Fourth, the size of each coloured segment is an approximate indicator of the kind of proportion a particular competence takes within the entire complex of the translator/translation specialist's communicative competence. This is to say that the bigger the segment, the more important the relevant sub-competence may be in the translating process. But all this segmentation can only be approximate, because the various competences or sub-competences may vary in importance or in their relative proportions with the different stages of teaching and with the objectives of each particular programme or course/subject.

And fifth, the arrows indicate the direction of development while the dotted lines mean that everything within the model, from social development (SD), language teaching (LT), and translator competence (including all its components), is openended. In other words, the translator/translation specialist competence is by nature an open-ended competence and the whole-person translator education model we propose is an open-ended life-long development model.

There is yet another thing to clarify before we move on to our main discussion of the above model. We realise that doubts may arise about why we call our model an "Inverted Pyramid." To explain, there are two considerations: Firstly, when we look at the diagram from upside down, we find it like the shape of a pyramid. And secondly, we quite believe that development of translators/translation specialists is very much like the "healthy growth" of children. As a "healthy diet" described by the Food Guide Pyramid is scientifically proven good for the growth of children, the same "Pyramid" concept seems to well reflect the true development nature of translator education. Re-set our inverted pyramid in its upside-down position and we will see a more recognisable form of a pyramid (Fig. 2). This would then help explain why we have used the "pyramid" concept for our translator education model. For the sake of easier reference and understanding, we will continue to use this "normalised" pyramid, rather than the original "inverted-pyramid" in any further discussions of our model below.

It will have been noticed that in our proposed whole-person translator education model, translation teaching, translation practice and translation theory are integrated intertextually into one system. This should be viewed as a reflection of the true nature 
of translator education as well as the provision of fundamental pedagogical guidelines for translation teaching. We will discuss and interpret this system from these important angles: Firstly, translator education at tertiary levels from undergraduate through postgraduate to doctorate is a system whose development plays an indispensable role in the establishment and development of translation studies as an independent academic discipline. An integrated model of a translation programme should reflect all the important phenomena in translation and translation education, and can contribute to the design and formation of clearly-defined objects of study. Any teaching and research programmes without definite objects for teaching and research would find it difficult to develop into anything disciplinary.

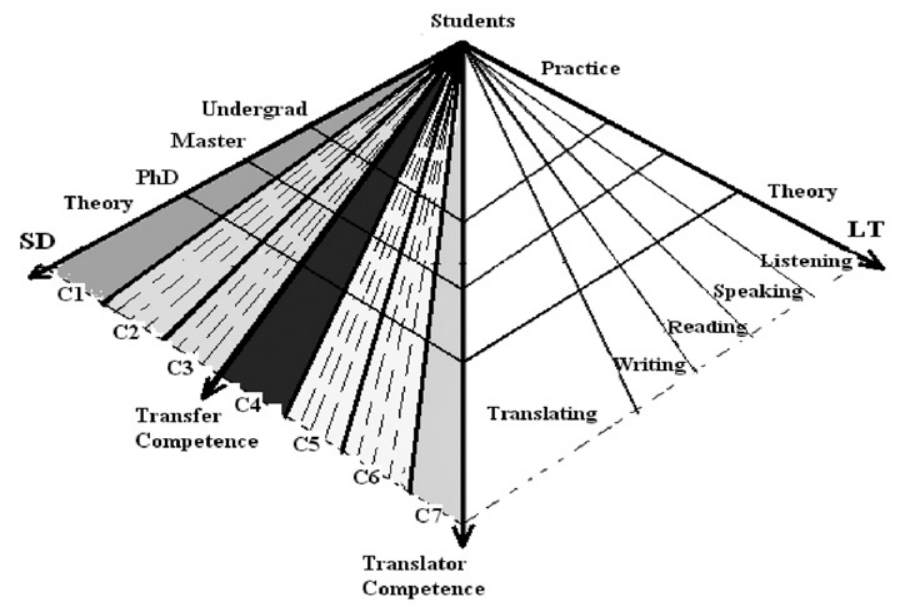

Fig.2: Whole-Person Translator Education Inverted-Pyramid (viewed from the perspective of a normal pyramid)

NB:

C1:

Cognitive Competence

Pragmatic Competence in L2

C5: $\quad$ Linguistic Competence in L1

C7: Instrumental Competence

Master: MA/MPhil Level

LT: Language Teaching

$\begin{array}{ll}\text { C2: } & \text { Linguistic Competence in L2 } \\ \text { C4: } & \text { Transfer Competence } \\ \text { C6: } & \text { Pragmatic Competence in L1 } \\ \text { Undergrad: } & \text { Undergraduate Level } \\ \text { PhD: } & \text { PhD Level } \\ \text { SD: } & \text { Social Development }\end{array}$

Second, real-life cognition is the very basis of our whole-person translator education model. The arrow-ended line on the left side of Fig. 2 denotes social development (SD), along which human cognitive competence develops with school language teaching (LT) and education, marked by the arrow-ended line on the right-hand side of the pyramid. Teaching and education at school should keep in mind what social missions they have to accomplish and try to foster by all means the competences students need in their future life. The three minor hierarchical pyramids marked by Undergrad, Master and $\mathrm{PhD}$ indicating translation education at the undergraduate, MA/MPhil and doctoral level on a translation programme means that different levels of education will satisfy different social demands and accomplish different social missions.

Thirdly, the practice of translation dominates a translation student's early stage of development while the learning of translation theory comes in gradually with the student's translational development. To put it in a different way, for translation 
teaching in a university translation programme, the practice of translation and the theory of translation take different proportions during different stages or on different levels. The lower the level, the less theory and more practice there is; the more advanced the level, the more theory and less practice. Besides, the deeper down the theory line runs towards the lower part of the pyramid, or in the direction of the arrows, the more profound and difficult the theory to be taught.

At the undergraduate level, students are more practice-oriented and are more exposed to practical translation problems. Tertiary translation education at the intermediate level, the level of MA and MPhil studies, can be branched into either more practice or more theory, as is reflected in taught MA and research MPhil programmes in translation in universities in Hong Kong. Those in taught MA translation programmes focus on translation practice and do more practical work than undergraduate students in a wider range of text and more real-life translation tasks; while those who undertake MPhil studies look more than MA students into the underlying laws of translation practice and formulate critical reflections on translation problems. $\mathrm{PhD}$ level education in translation aims at a yet higher level than MPhil level education and seek theories with greater explanatory power. Although students at the PhD level need to focus more than the lower levels of study on theoretical thinking, it would be wrong to claim or assume that $\mathrm{PhD}$ study is divorced from practice. The reason why $\mathrm{PhD}$ students in translation often seem separated from translation practice is due to the fact that they are less involved in performing translation tasks. However, in view of the fact that PhD translation students inevitably go deeper into translation phenomena, and look forward and backward at development trends and history of translation practice, they are actually closer to, rather than farther away from, the practice of translation.

Fourthly, like all other students as independent cognitive subjects, translation students develop cognitively, intellectually, technologically, psychologically and physiologically. During the various stages of their tertiary translation education, they grow as translators/translation specialists in their cognitive competence, bilingual communicative competence, transfer competence, instrumental competence and other competences. But the process of translation education does not end with their graduation or being awarded the various university degrees. It goes on with social development and translators/translation specialists continue their translation education by themselves in all such language skills as listening, speaking, reading, writing, and translating. In other words, like education in general, translation education is also a life-long process, as is denoted by the arrows and the open-ended lines of the pyramid.

Fifthly, translator competence is not a privilege solely belonging to translators or translation students. It is a competence open to all language learners, with varied degrees of proficiency depending on the amount of translation practice and translation theory they have undertaken. The more practice and theoretical thinking one undertakes, the more proficient one's translator competence becomes. Also, such translator competence is open to constant improvement. What distinguishes the translator/translation specialist from the general language user is that the former tends to have more specialised knowledge on the subject of translation than the latter. The former may have more expertise on the whys and hows about translation than the latter who may only have knowledge about the hows and whats. 
And finally, all these sub-components of translator competence and the five language skills are an integral whole. However, it is sometimes possible or even desirable to focus on this or that of the sub-competences and language skills during different periods or for different purposes. For example, those who are trained to be translators may focus more on the development of such aspects as grammatical, textual and instrumental competences, while those who would be interpreters may be more likely to focus on the phonological, interactional and functional competences. Both types of students or trainees, of course, would pay equal attention to the development of their cognitive, lexical and cultural competences. For students to become well-rounded and well-adjusted, translation teaching should aim to consolidate their knowledge base and develop a solid foundation for their pyramid of knowledge and competence. Students with such a pyramid of knowledge and competence will undoubtedly be more adaptable and competitive in the fast-changing market of translation and language services.

\section{Conclusion}

To conclude, we can highlight a few points about this discussion of translation teaching. First, for translation teaching in the new era of the $21^{\text {st }}$ century, it is important to take into consideration the rapid social changes and challenges translators or would-be translators are faced with. Translation teaching in a university translation programme being part of the whole system of the university as well as of society at large, it should reflect both the intrinsic laws of education and the ever-developing demands of society. Accordingly, everything involved in translation teaching, from issues on "why" through "what" and "when" to "how to teach," should be viewed and done so that it satisfies translational and social demands.

Secondly, it is important to make a distinction between translation teaching as training and as education, with the former emphasising the teaching and learning of translation skills and techniques, whereas the latter on a more holistic development of the students' overall intellectual and academic well-being. To our mind, real success for a university translation programme lies in its full recognition that translation teaching at the tertiary level is neither training alone nor education in abstraction, but it is both training and education. For its aims and objectives are to turn out students who are not only equipped with enhanced translation skills and techniques, but also have all the makings of a cultured, whole person, qualified to serve society both as a translation/translation specialist and as a innovative person.

From this concept of translation teaching as both training and education, then, comes our proposal for a new model of translation teaching, namely the Whole-person Translator Education Approach to translation teaching. Central to this approach is the proposition that students should be educated as well-rounded and well-adjusted translators or translation specialists; and this well-rounded and well-adjusted development of the students is materialised through a "healthy" way of teaching and educating. Represented by the diagram of a pyramid, our whole-person translator education model is characterised by its being an integrated network of competences with open-ended readiness for constant new development. With fitting emphasis on the teaching of translation practice and translation theory during the various stages of development or on the various programme levels from undergraduate through 
postgraduate to doctorate, the proposed model may well reflect the true nature of successful translation teaching at the tertiary level.

This above Whole-person Translator Education Model would imply at least two major changes in the way translation is taught, especially in universities in China. Firstly, no matter whether a degree programme in translation is offered by a comprehensive university (such as the Sun Yat-sen University in Guangzhou where a School of Translation has recently been set up with a planned annual intake of 500 students at the undergraduate level), or a specialised foreign language-cultural studies university (such as the Beijing, Shanghai and Guangzhou International Studies Universities where degree courses in translation are offered at both the undergraduate and postgraduate levels), or even a teacher education/training university (such as the Hunan Normal University where the first ever translation department was set up a few years ago in a teacher education/training institution in the PRC), the core subjects should be essentially the same, especially during the first two years (of a four-year programme) at university, so that students in all such programmes receive basic education and training in the fundamentals in language, culture and translation in the same way. And secondly, even during the second half of their four-year education and training when students branch into various streams with some doing literary translation, some translation for special purposes and some interpretation, it is still not wise to restrict the teaching to very narrow areas. For a narrowly specialised translation graduate is not likely to be ready to take up challenges from a rapidly changing society. For example, if an interpreting student trained for the 2008 Beijing Olympic Games only had knowledge and competence for that particular event, he/she would soon be displaced when the Games are over. However, if such a student had received a broad-based education in translation after which he/she had also gone through some special, on-the-job, training, he/she would be in a much better position to adapt to whatever new challenges face him/her, and at any time.

Indeed, it hoped that the mechanisms of such a model will provide a solid base to build a valid and effective methodology on for the teaching of translation in university translation programmes, especially those involving the language-combination of Chinese and English.

\section{NOTES}

1. This article is based on the paper presented by the author under the title "Translation teaching in the $21^{\text {st }}$ century: Towards a "Whole-person translator education' approach -With special reference to Chinese contexts," at the conference on "Professional Education of $21^{\text {st }}$ Century Translators and Interpreters," September 9-11, 2005, Monterey, California.

2. See <http://isg.urv.es/publicity/masters/courses/masters.html> (accessed on 2005-8-1).

3. See $<$ www.mypyramid.gov $>$.

4. See <www.mypyramid.gov/guidelines/index.html>.

\section{REFERENCES}

Alves, F. (ed.) (2003): Triangulating Translation: Perspectives in Process Oriented Research, Amsterdam, John Benjamins.

BAer, B. J. and G. S. Ковy (eds.) (2003): Beyond the Ivory Tower: Rethinking Translation Pedagogy, Amsterdam/Philadelphia, John Benjamins.

Beeby, A., Ensinger, D. and M. Presas (eds.) (2000): Investigating Translation, Amsterdam, John Benjamins. 
Bernardini, S. (2004): "The theory behind practice: translator training or translation education?," Translation in Undergraduate Degree Programmes (Kirsten Malmkjær, ed.), Amsterdam/Philadelphia, John Benjamins, pp. 17-30.

Blasi, P. (1999): "The task of institutions of higher education in the new Europe," in Hirsch, W. Z. and L. E. Weber (eds.), Challenges Facing Higher Education at the Millennium, Arizona, the American Council Education and the Oryx Press, pp. 26-33.

Bligh, D. (1990): Higher Education, London, Cassell Educational Limited.

HuANG, Z. (1997): "Fanyi nengli yu fanyi jiaoxue" (Translation competence and translation teaching), Shanghai Science and Technology Translators' Journal 3, pp. 26-31.

Hung, E. (ed.) (2002): Teaching Translation and Interpreting 4: Building Bridges, Amsterdam/ Philadephia, John Bejamins.

Kiraly, D. C. (1995): Pathways to Translation: Pedagogy and Process, Kent, Ohio, The Kent State University Press.

Kiraly, D. C. (2000): A Social Constructivist Approach to Translator Education: Empowerment from Theory to Practice, Manchester and Northampton, St. Jerome Publishing.

Labrum, M. B. (ed.) (1997): The Changing Scene in World Languages (American Translators Associations Scholarly Monograph Series, Vol. IX), Amsterdam/Philadelphia, John Benjamins.

LI, D. (2002): "Teaching information technology in translator training programs in Hong Kong," ATA Chronicle, pp. 29-33.

LI, D. (2003): "Translator training: What translation students have to say," Meta: Translators' Journal 47-4, pp. 513-531.

LI, D. (2005): "Teaching of specialized translation courses in Hong Kong," Babel: International Journal of Translation 51-1, pp. 1-16.

LiU, J., Lin, W. and S. Jin (eds.) (2000): Proceedings of Conference on Translation Teaching, Hong Kong, Hong Kong Translators' Association.

Liu, M. (2003): Fanyi Jiaoxue: Shiwu yu Lilun (Translation Teaching: Theory and Practice), Beijing, China Translation Corporation.

Liv, Z. (2001): Lun Fanyi Jiaoxue (On Translation Teaching), Beijing, The Commercial Press.

MACKENZIE, R. (2004): “The competencies required by the translator's role as a professional," in MalmkjÆr, K. (ed.), Translation in Undergraduate Degree Programmes, Amsterdam/ Philadelphia, John Benjamins, pp. 31-38.

Maia, B., Haller, J. and Margherita Ulrych (eds.) (2002): Training the Language Services Provider for the New Millennium, Porto, Facultdade de Letras, Universidade do Porto.

MalmkjÆR, Kirsten (ed.) (2004): Translation in Undergraduate Degree Programmes, Amsterdam/ Philadelphia, John Benjamins.

Mu, L. (1999): Zhongguo Fanyi Jiaoxue Yanjiu (A Study of Translation Teaching in China), Shanghai, Shanghai Foreign Language Education Press.

Mu, L. (2004a): A Critical Study of (C-E/E-C) Text-based Translation Testing for Translation Teaching: Towards Constricting a Fuzzy Synthetic Marking Model, Ph.D Thesis (written in Chinese), Hong Kong, Hong Kong Baptist University.

Mu, L. (2004b): "Fanyi jiaoxue yu fanyixue xueke fazhan" (Translation teaching and the disciplinary development of translatology), Chinese Translators Journal 3, pp. 37-38.

Neubert, A. (1994): "Competence in translation: a complex skill, how to study and how to teach it," in Snell-Hornby, M., Pöchhacker, F. and K. Kaindl (eds.), Translation Studies: An Interdiscipline, Amsterdam/Philadelphia, John Benjamins, pp. 411-420.

Neubert, A. (2000): “Competence in language, in languages, and in translation," in SCHÄFFner, C. and B. АдAв (eds.) Developing Translation Competence, Amsterdam/Philadelphia, John Benjamins, pp. 3-18.

NidA, E. A. (1997): “Translation in the information age," in Labrum, M. B. (ed.), The Changing Scene in World Languages (American Translators Associations Scholarly Monograph Series, Vol. IX), Amsterdam/Philadelphia, John Benjamins, pp. 9-18. 
Nord, C. (1999): "Translating as a text-production activity" (The original version of this paper was presented as a talk at the Universitat de Vic, Catalonia, Spain, in 1999), <http://www. fut.es/ apym/symp/nord.html>, accessed on 2005-7-20.

PACTE (2000): "Acquiring translation competence: hypotheses and methodological problems in a research project," in Beeby, A., Ensinger, D. and M. Presas (eds.), Investigating Translation, Amsterdam, John Benjamins, pp. 99-106.

PACTE (2003): "Building a translation competence model," in Alves, F. (ed.) Triangulating Translation: Perspectives in Process Oriented Research, Amsterdam, John Benjamins, pp. 78102.

Schäffner, C. and B. Adab (eds.) (2000): Developing Translation Competence, Amsterdam/ Philadelphia, John Benjamins.

SIL International (1999): "Aspects of communicative competence" (LinguaLinks Library, Version 3.5. Published on CD-ROM), online, accessible: <http://www.sil.org/lingualinks/LANGUAGE LEARNING/OtherResources/GudlnsFrALnggAndCltrLrnngPrgrm/AspectsOfCommunicativeCompeten.htm>, accessed on 2005-7-20.

Sin, K. K. (2000): "Fanyi jiaoxue de ben yu mo" (The end and the means of translation teaching), in Liu, J., Lin, W. and S. Jin (eds), Proceedings of Conference on Translation Teaching, Hong Kong, Hong Kong Translators' Association, pp. 13-25.

Sin, K. K. (2002): “Myths and misconceptions in translation teaching," in Hung, E. (ed.) Teaching Translation and Interpreting 4: Building Bridges, Amsterdam/ Philadephia, John Bejamins, pp. 31-43.

Weber, L. E. (1999): "Survey of main challenges facing higher education at the millennium," in Hirsch, W. Z. and L. E. Weber (eds), Challenges Facing Higher Education at the Millennium, Arizona, the American Council Education and the Oryx Press, pp. 3-17.

Widdowson, H. G. (1984): "English in training and education," in Widdowson, H. G (ed.), Explorations in Applied Linguistics 2, Oxford, Oxford University Press, pp. 201-211.

YANG, L. and B. Zhang (2003): "Dao yu ji - bei hulue de zhongguo fanyi jiaoxue wenti" (The way and the technique: Issues neglected in Chinese translation teaching), Chinese Science \& Technology Translators Journal 1, pp. 21-23.

Zhang, M. (1999): A Study of the Development of Translation Textbooks on the Mainland of China (1949-1998), Ph.D. Thesis (written in Chinese), Hong Kong, Hong Kong Baptist University.

Zhang, M. (2001): Zhong Yinghan Fanyi Jiaocai Yanjiu (1949-1998) (English/Chinese Translation Textbooks in China [1949-1998]), Shanghai, Shanghai Foreign Language Education Press. 